\title{
Monitoring of the Specific Absorption Rate in Terms of Electromagnetic Hazards
}

\author{
Joanna Michałowska ${ }^{1 *}$, Andrzej Wac-Włodarczyk², Joanna Kozieł² \\ 1 The State School of Higher Education, The Institute of Technical Sciences and Aviation, ul. Pocztowa 54, \\ 22-100 Chełm, Poland \\ 2 Electrical Engineering and Computer Science Faculty, Institute of Electrical Engineering and \\ Electrotechnologies, Lublin University of Technology, ul. Nadbystrzycka 38a, 20-618 Lublin, Poland \\ * Corresponding author's e-mail: jmichalowska@pwsz.chelm.pl
}

\begin{abstract}
High-frequency electromagnetic field monitoring is extremely important for the environment. Recording and continuous observation of the levels of harmful factors and their evaluation should be examined by means of systematic and reliable measurements. The purpose of the present research stems from the need for verification and analysis whether modern phones are safe for users during telephone conversations. The analysis was carried out with the use of two ESM 120 and ESM 140 meters measuring the same devices simultaneously. The SAR (Specific Absorption Rate) describes the energy processes in the biological tissues exposed to electromagnetic fields (EMF). The maximum values recorded by the ESM 140 dosimeter are $\mathrm{SAR}=0.5 \mathrm{~mW} / \mathrm{kg}$.
\end{abstract}

Keywords: SAR, electromagnetic field, mobile phone, hazards, meters, monitoring

\section{INTRODUCTION}

The research into the impact of the electromagnetic field on living organisms is underway in various research centers around the world. In today's era of wireless communication, it is important to monitor the electromagnetic field and assess its hazards.

The electromagnetic radiation has different effects, depending on the frequency on the field strength and frequency spectrum. The direct biological effects of EMF on the human body include [Mika and Michałowska, 2016]:

- Thermal effects

- Extra-thermal effects

Measuring techniques and computer simulations, as well as the analysis of technical parameters of technical objects emitting electromagnetic fields are used to identify, test and evaluate the parameters of exposure to electromagnetic fields.

Nowadays, the mobile telephony is the most popular communication system. In the last two decades, the mobile telephony has become the most popular radio communication system, enabling communication all over the world. Every device (every installation) in which current flows is a source of radiation, e.g. power grids, including high-voltage lines, radio and television stations, base stations and mobile phones, radios, CB-radios, radio-navigation devices or electrical appliances used at home. People are still afraid of the negative effects of the electromagnetic field on their health. The introduction of the new $5 \mathrm{G}$ technology $(3.4-3.8 \mathrm{GHz})$ operating in a higher frequency band than those currently in use is also a cause for the public concern [Bieńkowski et al., 2019, Gas and Miaskowski 2019, Józwik et al., 2018].

Among scientists in the country and around the world, the SAR plays a very important role. It is an averaged whole-body or local measure of thermal action due to the body's thermal load due to EMF action at frequencies between $100 \mathrm{kHz}$ and $6 \mathrm{GHz}$ (RMS value averaged over any 6-minute period of exposure). It is determined by the performance characteristics of the human 
thermoregulatory system. The definition of SAR was given in the paper [Michałowska and Józwik 2019, Michałowska et al., 2018].

Despite numerous studies and extensive analyses of the impact pertainin $g$ to the electromagnetic field on the environment, its negative impact has not been clearly identified. The analyses of EMF and SAR distribution are the basis for estimating the electromagnetic exposure [Michałowska et al., 2019].

\section{LEGAL RECOMMENDATIONS}

National environmental monitoring analyzes and evaluates electromagnetic fields. The Chief Inspector of Environmental Protection testing of electromagnetic field levels in accordance with the Act. The measurements of electromagnetic fields within the framework of the Environmental Protection Agency are carried out in a uniform manner for the whole country since 2008 [www.gios.gov.pl].

On the territory of each province, there is a network of 135 measurement points in which measurements are conducted in a three-year cycle of 45 points per year. The points are evenly distributed in the province, 15 points each, over three types of areas accessible to the population.

- central districts or city districts with a population exceeding 50,000;

- other cities;

- rural areas

The scope and manner of periodical research of electromagnetic field levels in the environment is specified in the Regulation of the Minister of the Environment of 12 November 2007. (Journal of Laws No. 221, item 1645) [Kurgan and Gas, 2010, Mazurek et al., 2018, Mazurek et al., 2016].
The Directive 2013/35 /EU defines the current ranges of electromagnetic fields in the EU member states.

\section{EXPERIMENTAL STUDIES AND THEIR RESULTS}

The study was conducted at the Centre of Engineering Studies of the State School of Higher Education (Pol. PWSZ) in Chelm within the project "Laboratory of Environmental Studies CSI PWSZ in Chelm," co-financed by the European Fund of Regional Development (part of the Operational Programme Eastern Poland) 2007-2013.

The Specific Absorption Rate measurements were carried out with the Maschek ESM 120 meter and the Maschek ESM 140 dosimeter in an environmental laboratory. The Specific Absorption Rate was measured during 6-minute calls made using mobile phones of various manufacturers. The results for the following selected models of mobile phones were presented: 1 . Xiaomi Redmi 7, 2. iPhone 8, 3. Samsung Galaxy ACE III, 4. iPhone X, 5. LG Q60. The results were recorded at the same time with two different measuring devices in order to check whether the obtained values comply with the European Directive and the obtained values are of the same order.

The ESM 120 is an innovative SAR measurement device for GSM 900 and $1800 \mathrm{MHz}$ frequencies. The parameters of the meter were described in [Michałowska et al., 2018].

The ESM 140 measures the electric field strength for high frequencies such as $900 \mathrm{MHz}$, GSM1800, DECT, UMTS, WLAN and its characteristics were presented in [Michałowska et al., 2018].

The measurements started with placing the mobile phone in the tripod of the ESM 120. Then
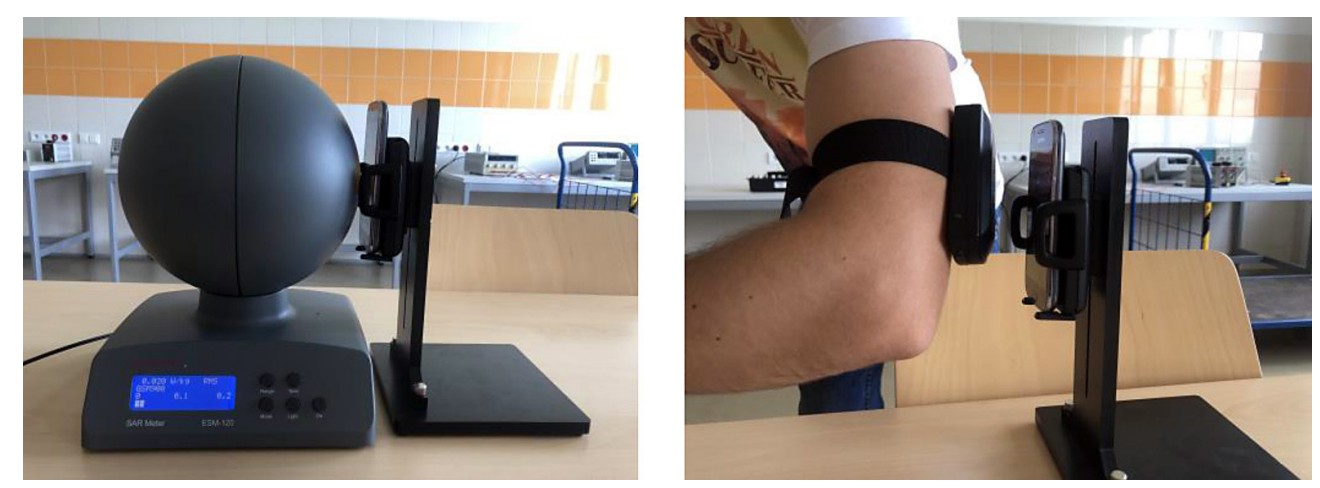

Fig. 1. Measurement of SAR a mobile phone: a) ESM 120 meter, b) ESM 140 dosimeter 
a telephone call was made. The results of the ongoing telephone call for 6 minutes were analysed. At the same time, measurements were performed with the ESM 140 dosimeter, which was placed near the ESM 120 meter.
Figures 2, 3, 4, 5 show the results of selected SAR measurements with the ESM 120. The measurements were made for the GSM 900 frequency band, which received the largest signal in the environmental research laboratory of the State
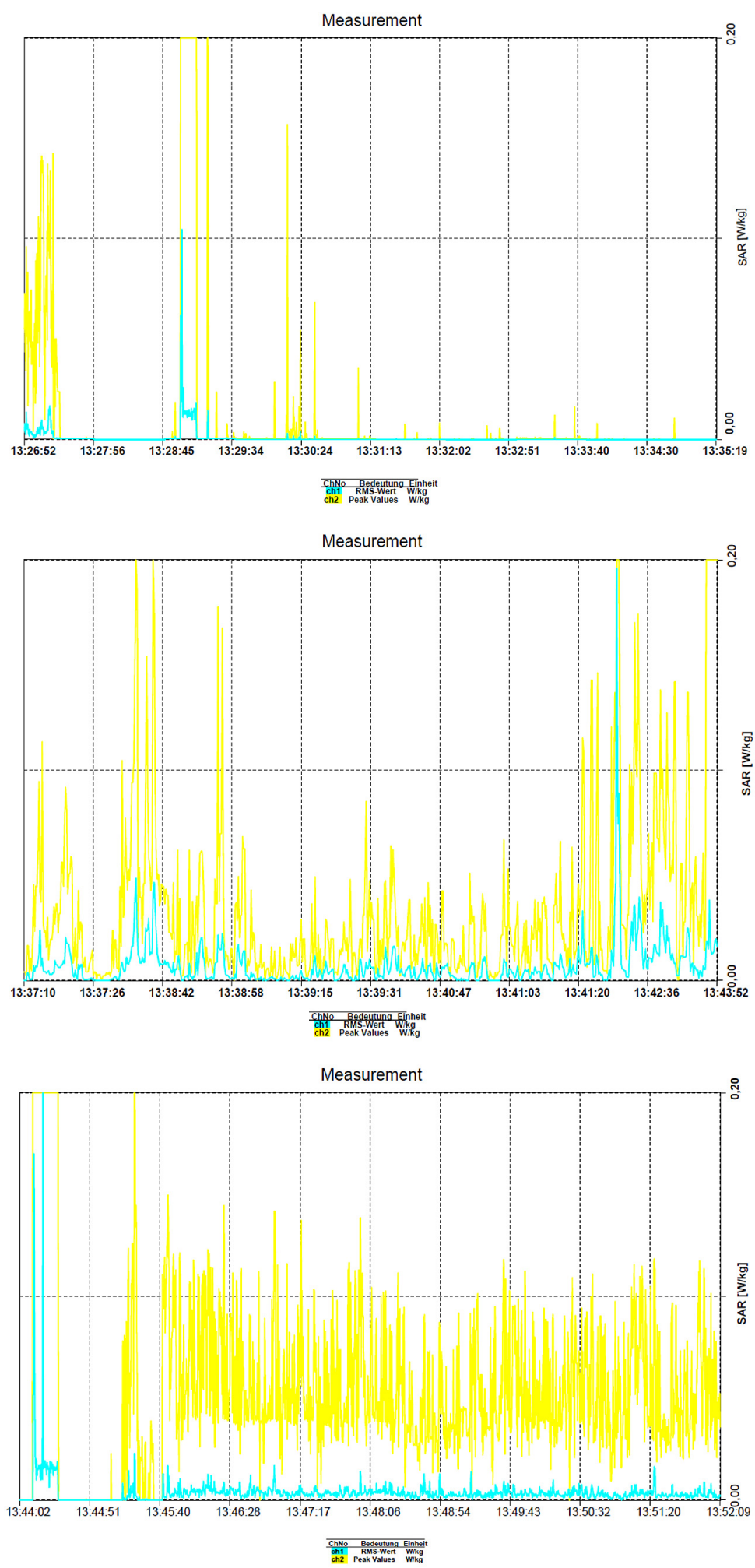

Fig. 2. Results of a mobile phone specific absorption rate SAR measurement performer with the EMS 120 measuring device: a) telephone No. 3, b) telephone No. 1, c) telephone No. 4 
School of Higher Education of Chełm. The results of the analysis were presented for the RMS values (the mean values displayed) as well as for Peak (the maximum values displayed).

Highest values $\mathrm{SAR}_{\mathrm{RMS}}=0.2 \mathrm{~W} / \mathrm{kg}$ and $\mathrm{SAR}_{\text {Peak }}=0.35 \mathrm{~W} / \mathrm{kg}$. Figures 3,4 and 5 show the results of measurements of the Absorption coefficient with the ESM 140 dosimeter. The measurements were performed in the GSM 900 up (880-915 MHz) and GSM down (925-960 MHz) frequency bands.

The measurement values shown in Figures 3, 4 and 5 are presented separately for RMS and Peak values due to the impossibility to generate them from the memory of the 140 dosimeter in such a way as to place them on one graph. The characteristics obtained by the measurement show that the highest maximum values of $\mathrm{SAR}=1.24 \mathrm{~mW} / \mathrm{kg}$.

\section{STATISTICAL ANALYSIS OF THE SPECIFIC ABSORPTION RATE}

The SAR values obtained from the measurements with the ESM 120 and ESM 140 meter were implemented in the Statistica 13.3 software for statistical analysis. The study involves the analysis of 420 measurements for each variable. The values of the analysed variables are described by mean, media, standard deviation and range of variability. The researchers assumed error of inference that equaled $5 \%$ and level of significance of $\mathrm{p}<0.05$.

The chart of data with the range of variability showing the median and the lower and upper quartiles for a selected group of telephones obtained from ESM 140 measurements is shown in Figure 6. a)

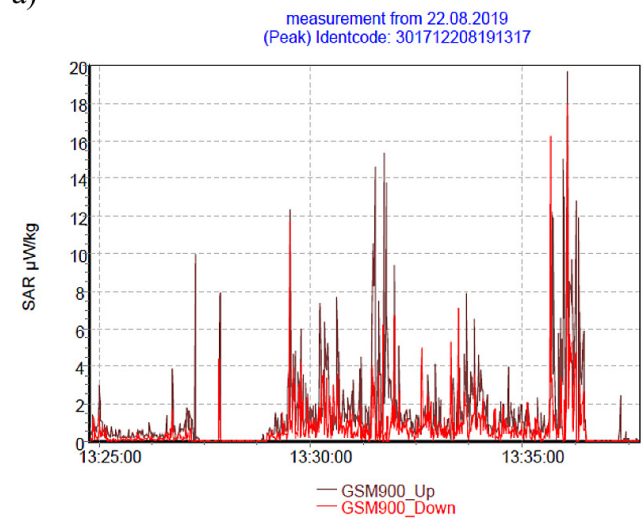

b)

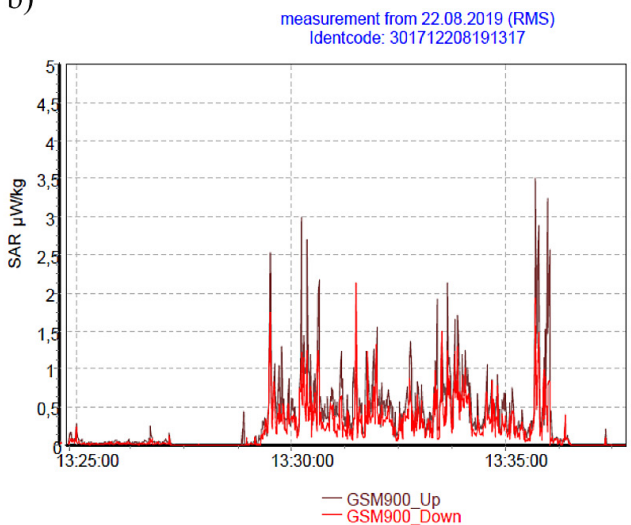

Fig. 3. Measurements of specific absorption rate of mobile phone number three performed with the EMS 140 measuring device: a) RMS value, b) Peak value

a)

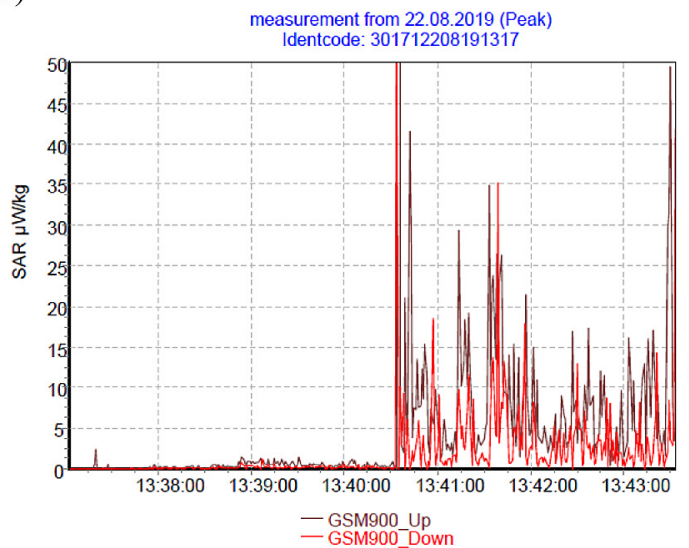

b)

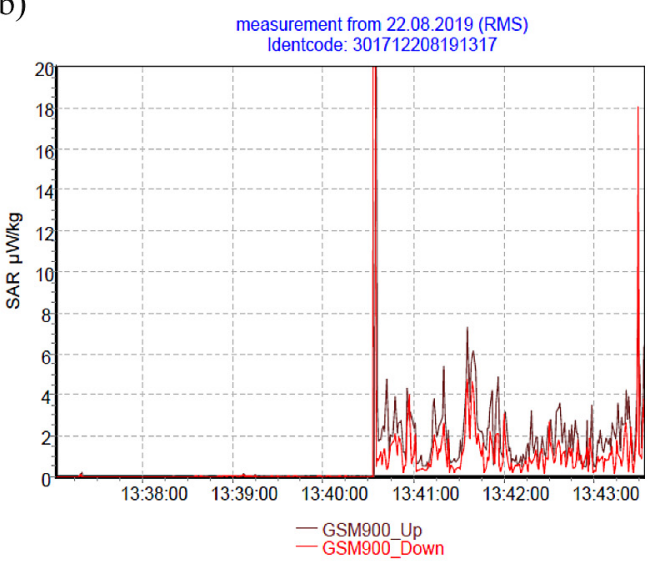

Fig. 4. Measurements of specific absorption rate of mobile phone number one performed with the EMS 140 measuring device: a) RMS value, b) Peak value 
a)

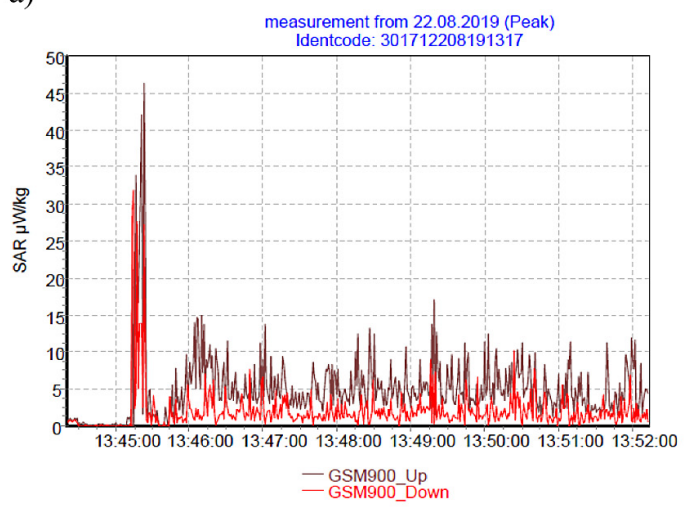

b)

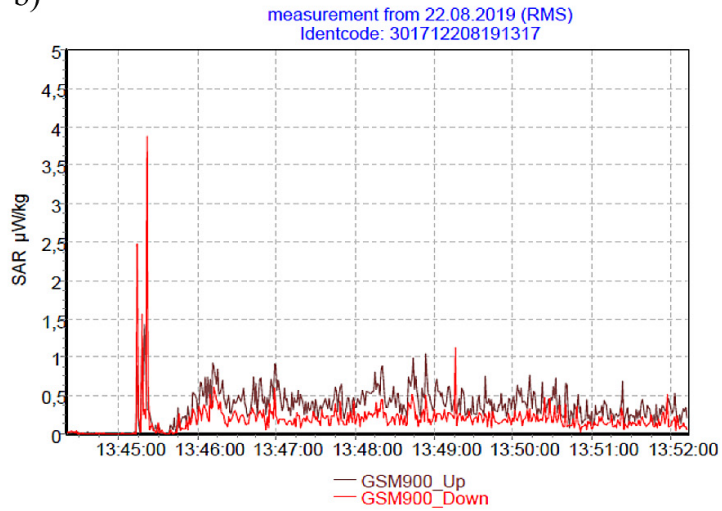

Fig. 5. Measurements of specific absorption rate of mobile phone number four performed with the EMS 140 measuring device: a) RMS value, b) Peak value

The mean value of the specific absorption rate for the analysed phones ranges from $0.06 \mathrm{~mW} / \mathrm{kg}$ to $0.33 \mathrm{~mW} / \mathrm{kg}$. Variation of the study characteristic ranges from $0 \mathrm{~mW} / \mathrm{kg}$ to $1.23 \mathrm{~mW} / \mathrm{kg}$. In the Figure 6 we can see that the maximum values were registered for the telephone number.

In order to verify the results of measurements with the ESM 120 meter and ESM 140 dosimeter, a comparative analysis was performed for Peak values in the GSM 900 frequency band. The SAR characteristics for selected groups of phones were shown in Table 1, giving the mean, median, range of variability and standard deviation.

The data chart with the range of variability presented the median and the lower and upper quartiles for a selected group of phones in relation to the measurement with the ESM 120 meter is shown in Figure 7.
Figure 7 shows that the maximum values for ESM 120 and ESM 140 of the same telephones differ significantly from each other. The highest values were achieved for phone No. 1.

\section{CONCLUSIONS}

The obtained measurement results were referred to the European Union directive [Directive 2013/35/UE]. The limit values of SAR = $0.4 \mathrm{~W} / \mathrm{kg}$ for GSM 900 frequency were not exceeded in any of the measurements. The tests showed that the tested equipment meets the standards included in the European Directive. The maximum measured values of the Specific Absorption Rate are SAR $=0.2 \mathrm{~W} / \mathrm{kg}$. These are average values. The measurements of the

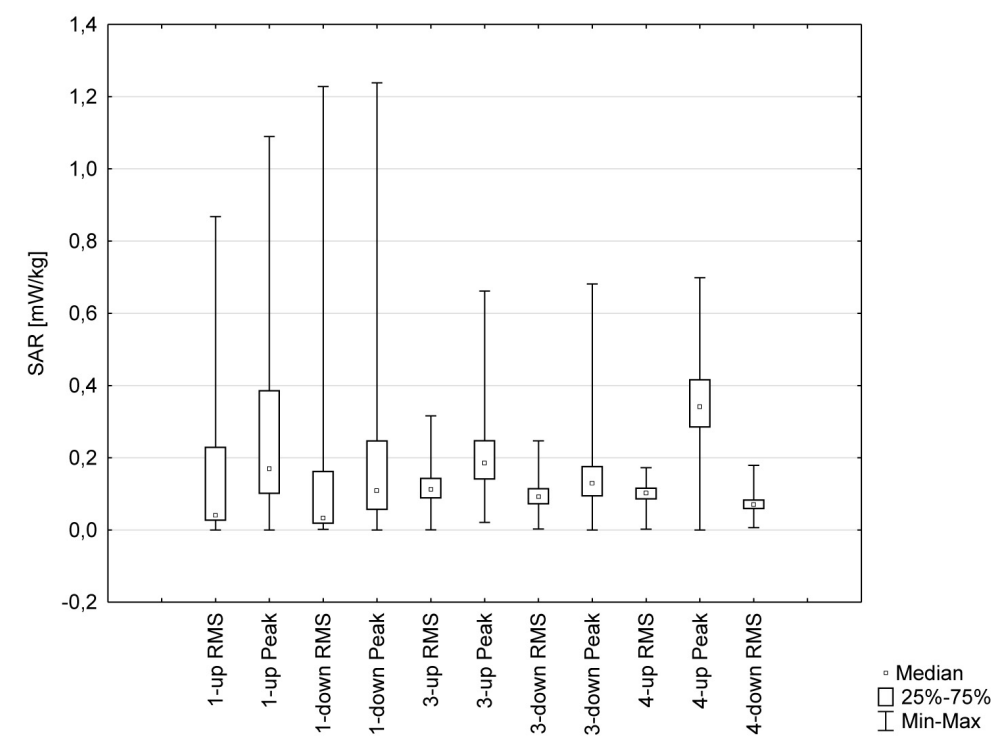

Fig. 6. Raw graph of the range of median variability of selected phones 
Table 1. Characteristics of the specific absorption rate

\begin{tabular}{|c|c|c|c|c|c|c|c|}
\hline Variable & Mean & Min & Max & SD & Median & Lower quartile & Upper quartile \\
\hline 1-ESM140 & 0,170 & 0,00 & 1,238 & 0,167 & 0,108 & 0,055 & 0,248 \\
\hline 3-ESM140 & 0,144 & 0,00 & 0,681 & 0,079 & 0,129 & 0,092 & 0,177 \\
\hline 4-ESM140 & 0,200 & 0,00 & 0,540 & 0,098 & 0,199 & 0,148 & 0,253 \\
\hline 3-ESM120 & 0,002 & 0,00 & 0,456 & 0,031 & 0,000 & 0,000 & 0,000 \\
\hline 3-ESM120 & 0,002 & 0,00 & 0,456 & 0,031 & 0,000 & 0,000 & 0,000 \\
\hline 4-ESM120 & 0,083 & 0,00 & 0,185 & 0,040 & 0,0820 & 0,046 & 0,118 \\
\hline
\end{tabular}

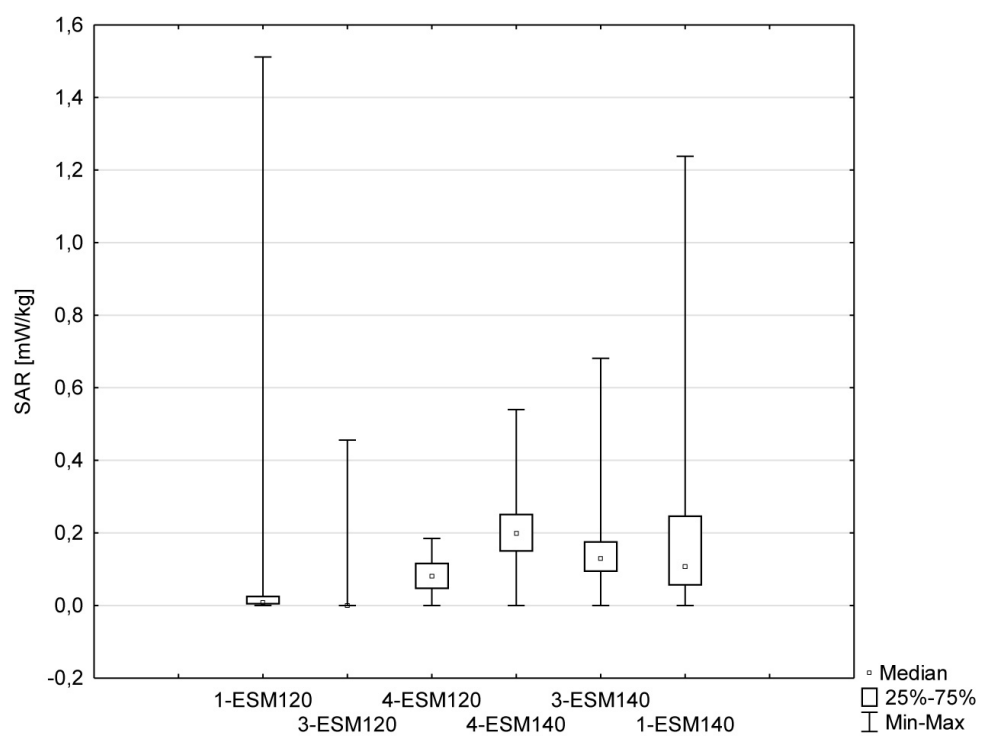

Fig. 7. Raw graph of the median variation range for the measurement of the specific absorption rate with ESM 120 and ESM 140

same values with the ESM 120 and ESM 140 differ from each other. Monitoring the Specific Absorption Rate in the context of human health and electromagnetic disturbances is very important. During the measurements, special attention was paid to the fact that phones are always wirelessly connected via the same frequency band $(900 \mathrm{MHz})$. The analysis shows that the results for the same devices differ when placed in the vicinity of one another.

\section{REFERENCES}

1. Bieńkowski P., Karpowicz J., Kieliszek J. 2016. Przegląd miar skutków narażenia na zmienne w czasie pole elektromagnetyczne i właściwości metrologicznych mierników, istotnych podczas oceny narażenia w środowisku pracy., Podstawy i Metody Oceny Środowiska Pracy, 4(90), 41-74

2. Directive 2013/35/UE of the European Parliament and the Council of 26 June 2013 on the minimum health and safety requirements regarding the exposure of workers to the risks arising from physical agents (electromagnetic fields) (20th individual Directive within the meaning of Article 16(1) of Directive 89/391/EEC) and repealing Directive 2004/40/EC

3. Gas P., Miaskowski A. 2019. SAR optimization for multi-dipole antenna array with regard to local hyperthermia, Przegląd Elektrotechniczny, vol. 95, no. 1, 17-20, doi: 10.15199/48.2019.01.05,

4. Józwik J., Wac-Włodarczyk A., Michałowska J., Kłoczko M. 2018. Monitoring of the noise emitted by machine tools in industrial environments, Journal of Ecological Engineering, vol. 19, no. 1, 83-93, doi: 10.12911/22998993/79447

5. Kurgan E., Gas P. 2010. Estimation of Temperature Distribution Inside Tissues in External RF Hyperthermia, Przeglad Elektrotechniczny, vol. 86, no. 1, $100-102$

6. MazurekP., MichałowskaJ.,KoziełJ., GadR.,Wdowiak A. 2018. The intensity of electromagnetic fields in the range of GSM 1800 DECT, UMTS,WLAN inbuilt-up areas, Przegląd Elektrotechniczny, nr 12, r. 94, 202-205, doi:10.15199/48.2018.12.45.

7. Mazurek P., Boś B., Wdowiak A. 2016. Wybrane zagadnienia pomiaru pól wysokich częstotliwości w środowisku, Przegląd Elektrotechniczny, vol. 92, 
nr 12 , s. $93-96$

8. Mika D., Michałowska J. 2016. Normatywne pomiary czynników szkodliwych na stanowisku pracy operatora obrabiarek sterowanych numerycznie, Przegląd Elektrotechniczny, R. 92, nr 12, 97-100,

9. Michałowska J, Józwik J. 2019. Prediction of the parameters of magnetic field of CNC machine tools, Przegląd Elektrotechniczny , ISSN 0033-2097, R. 95 NR $1 / 2019$ pp. 134-136 doi:10.15199/48.2019.01.34

10. Michałowska J., Tofil A., Józwik J., Pytka J., Budzyński P., Korzeniewska E. 2018. Measurement of high-frequency electromagnetic fields in CNC machine tools area, The 4th IEEE International Symposium on Wireless Systems within the International Conferences on Intelligent Data Acquisition and Advanced Computing Systems, Ukraine IEEE Xplore: 08 November 2018, doi.
DOI: 10.1109/IDAACS-SWS.2018.8525605

11. Michałowska J., Mazurek P., Gad R., Chudy A., Kozieł J.2019. Identification of the Electromagnetic Field Strength in Public Spaces and During Travel, Applications of Electromagnetics in Modern Engineering and Medicine (PTZE), doi: 10.23919/ PTZE.2019.8781737;

12. Michałowska J., Kozieł J., Wac -Włodarczyk A. 2018. Influence of The Mobile Phone on the $\mathrm{Hu}-$ man Organism During a Telephone call, Journal of Medical Technologies; 1(18): 1-12,

13. Rozporządzenie Ministra Środowiska z dnia 30 października 2003r. w sprawie dopuszczalnych poziomów pól elektromagnetycznych w środowisku oraz sposobów sprawdzania dotrzymania tych poziomów. Dz. U. z 2003 r. nr 192, poz. 1883.

14. www.gios.gov.pl/pl/stan-srodowiska/ monitoring-pol-elektromagnetycznych 